\title{
Inventory of Radiation Protection in Hospitals of Level III in Senegal
}

\author{
Boucar Ndong1, Sidi Ahmed Dia², Mamadou Salif Djigo', Herbert Fachinan3, \\ El Hadji Lamine Bathily1, Ousseynou Diop1, Kanta Ka4, Gérard Léra Kelvin Akpo5, \\ El Hadji Fallou Diouf 6 , Louis Auguinstin Diaga Diouf', Pape Mady Sy6, Alphonse Djiboune, \\ Gora Mbaye $^{6}$, Maguette Diagne ${ }^{7}$, Omar Ndoye $^{1}$, Mamadou Mbodji ${ }^{1}$
}

\author{
${ }^{1}$ Laboratoire de Biophysique, Médecine Nucléaire, Universite Cheikh Anta Diop, Dakar, Senegal \\ ${ }^{2}$ Service de Médecine du Travail, Universite Cheikh Anta Diop, Dakar, Senegal \\ ${ }^{3}$ Faculté de Médecine, Université de Parakou, Parakou, Benin \\ ${ }^{4}$ Service de Radiothérapie de Dalal Jamm, Dakar, Senegal \\ ${ }^{5}$ Service de Radiologie de l'Hôpital Aristide Le Dantec, Dakar, Senegal \\ ${ }^{6}$ Laboratoire de Physique Pharmaceutique, Universite Cheikh Anta Diop, Dakar, Senegal \\ ${ }^{7}$ Service de Radiothérapie de l'Hôpital Aristide Le Dantec, Dakar, Senegal \\ Email: ndongboucar73@yahoo.fr
}

How to cite this paper: Ndong, B., Dia, S.A., Djigo, M.S., Fachinan, H., Bathily, E.H.L., Diop, O., Ka, K., Akpo, G.L.K., Diouf, E.H.F., Diouf, L.A.D., Sy, P.M., Djiboune, A., Mbaye, G., Diagne, M., Ndoye, O. and Mbodji, M. (2021) Inventory of Radiation Protection in Hospitals of Level III in Senegal. Open Journal of Biophysics, 11, 397- 406.

https://doi.org/10.4236/ojbiphy.2021.114016

Received: September 4, 2021

Accepted: October 26, 2021

Published: October 29, 2021

Copyright $\odot 2021$ by author(s) and Scientific Research Publishing Inc. This work is licensed under the Creative Commons Attribution International License (CC BY 4.0).

http://creativecommons.org/licenses/by/4.0/

Open Access

\begin{abstract}
The aim of this study was to evaluate the level of protection of employees who are exposed to radiation in a level III hospital establishment. It was a descriptive cross-sectional survey of six months' duration, involving eight level III Hospitals (Aristide Le Dantec, Fann, Hoggy, Hear, Abass Ndao, Pikine, Touba, and Thiès) in Senegal. Sixty-one of the one hundred questionnaires were recovered (overall response rate of $61 \%$ ). The population of the study was mainly female (54.1\%). The average age was 38.57 with extremes ranging from 23 to 65 years old. In the places where ionizing radiation sources are handled, only at the Aristide Le Dantec Hospital did we find a "competent person in radiation protection". This explained the lack of a classification of employees and work areas. Forty out of sixty-one (73.77\%) had no knowledge of the basic principles of radiation protection (justification, optimisation, dose limitation) and had not ever taken radiation holidays. For radiovigilance, exposure time limits to ionizing radiation concerned only $29 / 61$ or $47.54 \%$ of the study population. The inverse square law of distance was known by only 40 workers, of whom 15 had no compliance. We found the presence of dosifilms in only $7 / 61$ or $11.47 \%$ of the workers. On the other hand, the use of lead aprons was well established and concerned 57/61 workers, i.e., 93.44\%. In sum, ionizing radiation causes adverse health effects. The absence of a good radiation protection culture in Senegal requires the presence of at least 4 to 5 competent persons in radiation protection for quality training of workers in radiobi-
\end{abstract}


ology, radiopathology and radiation protection.

\section{Keywords}

Ionizing Radiation, Radiation Protection, Workers, Senegal

\section{Introduction}

Ionizing radiation is widely used in the medical field for diagnoses and therapies. In Senegal, we are witnessing the use of increasingly important equipments, standard X-ray machines, computer tomography and linear particle accelerators [1]. SANE et al. [2] showed an insufficient level of knowledge of physician in terms of patient radiation protection and an underestimation of radiation-induced cancers that may result from any exposure. Hence the implementation of radiation protection measures for nearly a century. To avoid unnecessary exposure of patients and workers, three main principles such as justification, optimization and dose limitation have been established by international and national organizations [3]. And to respect these principles, radiation protection rules and measures have been defined such as the respect for distance, wearing a lead apron and exposure time. This work will show the level of application of these radiation protection rules and practices in level III health structures in Senegal.

\section{Material and Study Method}

The study was carried out in eight medical imaging departments of level III hospitals, six of which were in the capital (Aristide de Ledantec, Fann, Hôpital Général Idrissa Pouye, Albert Royer, Abass Ndao, Pikine), one in the Thiès region (Thiès hospital) and one in the Diourbel region (Fawzaini hospital). This was a prospective cross-sectional study lasting six months. A questionnaire was sent to the highest authority in the hospital before being distributed to the target group, which included radiologists, doctors in training, medical imaging technicians, assistant technicians, stretcher bearers, secretaries and other administrative staff. Several parameters were of interest to us in the course of the study, namely demographic data, radiation source, exposure time, zoning, compliance with the radiation holiday, worker classification and individual radiation protection equipment (wearing of dosifilm, lead apron, glasses, etc.).

\section{Results}

\subsection{Socio-Demographic Aspects}

Sixty-one of the 100 forms (61\%) were completed. The female sex participating in the survey was largely dominant $(85 / 100)$. The average age of the workers was 38.57 years, with extremes of 23 and 60 years. The modal age was 40 years and the median age was 37.5 years. The table below (Table 1) represents the distribution of workers. 
Table 1. Distribution of workers according to their place of work.

\begin{tabular}{ccc}
\hline Hospital structures & Workforce & Percentage (\%) \\
\hline HEAR & 01 & 1.64 \\
CHAN & 10 & 16.9 \\
CHFANN & 11 & 18.03 \\
HALD & 21 & 34.83 \\
HOGGY & 06 & 09.84 \\
FAWZAINI & 03 & 04.92 \\
PIKINE & 05 & 08.20 \\
THIES & 04 & 06.56
\end{tabular}

Figure 1 shows the different proportions of socio-professional categories.

Figure 2 shows the distribution of employees according to seniority.

\subsection{Regulatory Framework}

Of the eight hospitals, with the exception of the radiotherapy department of the Aristide de Le dantec hospital, none had a competent person in charge of radiation protection (PCR).

With regard to workers' knowledge of the regulations, forty-five workers (73.77\%) had no knowledge of the regulations. This lack of knowledge of the texts largely concerned assistant technicians in most cases $(9 / 10)$, followed by doctors $(5 / 10)$, technicians (3/10) and an almost total lack of knowledge of these texts by secretaries, stretcher-bearers and the other components. These workers have no knowledge of the texts.

As for workers' radiological leave, three quarters (75\%) have never had any leave related to ionizing radiation.

\subsection{Exposure Parameters}

Sources of exposure

The X-ray tube was the main source of exposure to ionizing radiation in the eight hospitals.

Modality of medical imaging examination

During the study period, several types of medical imaging examinations were performed. Table 2 presents the modalities of medical imaging examinations performed by the employees.

Duration of daily exposure

The duration of daily exposure to ionizing radiation varied from one centre to another and from one occupational category to another during our study. It varied from two hours to more than eight hours. Table 3 shows the distribution of the average daily exposure time by category of employee.

Workplace layout and zoning

None of the facilities surveyed had a posted floor plan or zoning according to their level of exposure. 


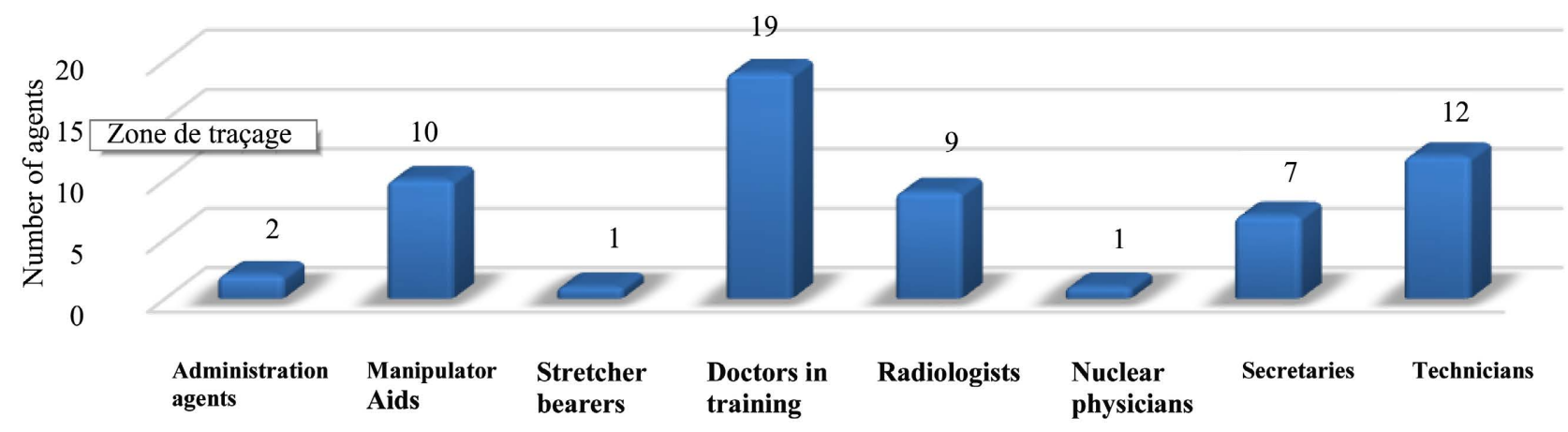

Figure 1. Distribution of surveyed staff in medical imaging departments according to socio-professional category.

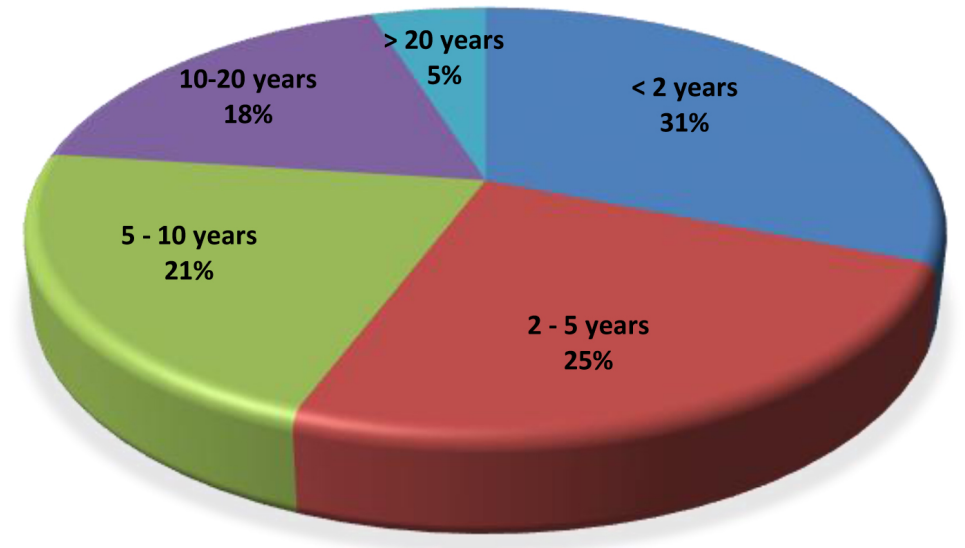

Figure 2. Distribution of employees according to seniority.

Table 2. Modalities of medical imaging examinations carried out by the employees.

\begin{tabular}{cc}
\hline Examination modality & Number of employees \\
\hline Dental panorama & 1 \\
Conventional radiography & 55 \\
Mammography & 44 \\
Computed tomography & 43 \\
Interventional radiology & 1 \\
Scintigraphy & 1 \\
\hline
\end{tabular}

Table 3. Distribution of the average daily duration of exposure by category of employee.

\begin{tabular}{|c|c|c|c|c|c|c|c|}
\hline \multirow{2}{*}{$\begin{array}{c}\text { Average } \\
\text { exposure time }\end{array}$} & \multicolumn{7}{|c|}{ Category of employees } \\
\hline & $\begin{array}{l}\text { Handling } \\
\text { assistants }\end{array}$ & Technicians & $\begin{array}{l}\text { Medical } \\
\text { doctors }\end{array}$ & Secretaries & Other & Total & $\begin{array}{c}\text { Percentage } \\
(\%)\end{array}$ \\
\hline 2 hours & 0 & 0 & 1 & 0 & 0 & 1 & 1.64 \\
\hline 4 hours & 0 & 0 & 8 & 0 & 0 & 8 & 13.11 \\
\hline 6 hours & 3 & 3 & 12 & 1 & 1 & 21 & 34.83 \\
\hline 8 hours & 3 & 7 & 7 & 5 & 1 & 23 & 37.71 \\
\hline More than 8 hours & 4 & 1 & 1 & 1 & 1 & 8 & 13.11 \\
\hline
\end{tabular}




\subsection{Radiological, Dosimetrical and Medical Monitoring}

No radiological monitoring was carried out in the hospitals studied.

The use of passive dosimeters worn on the chest was observed only in seven workers exposed to ionizing radiation, i.e., $11.47 \%$ of workers. The dosimeters were collected quarterly and processed in France in approved institutes.

None of the health facilities subjected the staff to a medical examination (at the time of hiring, periodically and when returning to work) or to additional radio monitoring examinations (CBC, chest X-ray, ophthalmological, dermatological and ENT examinations). No worker exposed to ionizing radiation had a medical file containing the regulatory information.

\subsection{Compliance with Radiation Protection Measures}

Reduction of exposure time

The daily time spent in the medical imaging room ranged from two hours to over eight hours.

Due to work constraints, thirty workers $(49.18 \%)$ remained in the room while the $\mathrm{X}$-ray tube was active.

Eight workers $(13.11 \%)$ were in the room outside of work constraints while the X-ray tube was inadvertently activated due to the absence of light signals. In addition, twenty-nine (29) workers had not reduced their exposure time, i.e. $47.54 \%$ of the workers.

Nine doctors, i.e., one third of their workforce, had not alternated their shifts, five radiology technicians (41.66\%) and six assistant radiographers had not done so either.

Distance from the Source

Fifteen workers, or $24.6 \%$ of the workforce in the imaging departments, did not concern themselves with the regulatory distance from the source of ionizing radiation.

Interposition of protective screens

The plumber's apron was the most commonly used personal protective equipment. Fifty-seven workers under ionizing radiation, i.e. 93.44\%, wore personal protective equipment if the situation required it. Figure 3 shows the distribution of the wearing of personal protective equipment by category of worker.

\begin{tabular}{|c|c|}
\hline No port & 4 \\
\hline Others & 3 \\
\hline Secretaries & 3 \\
\hline Doctors & 30 \\
\hline Technicians & 11 \\
\hline Manipulator Aids & 10 \\
\hline
\end{tabular}

Figure 3. Distribution of the wearing of personal protective equipment by category of worker. 


\section{Discussion}

\subsection{Socio-Demographic Aspects}

The staffs in the radiology departments of level III hospitals are relatively young, with an average age of 37.5 years. The majority of these staffs are female, with an estimated ratio of women to men of 0.85 . As a result, there should be special monitoring of radiation protection as there are a significant number of individuals of childbearing age in this population. Thus, any pregnancy should be reported to the occupational physician for appropriate management in the absence of PCR observed in most medical imaging departments [4]. The young nature of the population studied is another reason to tighten up radiation protection measures, as Bergonié Tribondeau's law of 1906 specifies that the cells of young subjects, which multiply rapidly, are the most radiosensitive, unlike the well-differentiated cells of older subjects, which are not very radiosensitive in principle.

\subsection{Regulatory Framework and Presence of a Competent Person in Radiation Protection}

The rules of radiation protection are not country-specific, but result from guidelines provided worldwide. Standards or recommendations are established at international level by different organizations. The International Atomic Energy Agency (IAEA) publishes and regularly revises standards in the fields of nuclear safety and radiation protection based on ICRP recommendations [4].

In Senegal, the organization of radiation protection is governed by three fundamental texts that define the general principles and establish the legal means for their actions [5]. Efficient control of nuclear activities to ensure the protection of workers, the environment and patients against ionizing radiation is accompanied by penal sanctions in case of infringement of this legislation [5]. In our study, the lack of knowledge of the regulations among most of our study population is largely explained by the absence of a PCR. A similar observation was made by Jaouad in Morocco in a study on the radiation protection of workers in Morocco. He noted in 2013 that $43 \%$ of his study population was unaware of the texts governing radiation protection due to the absence of a PCR in most imaging centres [6]. And this lack of PCRs is found almost everywhere. Indeed, Kouassi et al. in 2005 observed the presence of a PCR in 16.67\% of the facilities surveyed in Abidjan in Côte d'Ivoire [7]. Tapsoba et al. in 2010 found that only $5.9 \%$ of radiology departments in Ouagadougou in Burkina Faso had a PCR [8]. However, studies carried out by Khaled et al. in 2010 found a high frequency of PCR with 50\% of imaging centres having it. Thus, Sidi Bel-Abbés in Algeria [9] found a clear culture of radiation protection among these workers, contrary to what happens in West Africa and particularly in Senegal. Indeed, the PCR ensures the implementation of radiation protection measures. She is responsible and specially trained, with a knowledge check every five years. This implementation is based on regulatory texts that define in particular the controls of personnel, premises and ionizing radiation sources. This PCR implements all the ne- 
cessary measures to reduce exposures as little as possible in order to achieve a resolved image or effective treatment. It is this person who organizes the dosimetric monitoring of category A and B personnel, controls the ambient exposure rate, searches for contamination, and monitors the entry and exit of ionizing radiation and the storage of radioelements in nuclear medicine. It also provides staff training and enables the dissemination of a "radiation protection culture" which requires unfailing vigilance and rigorous working conditions.

\subsection{Exposure Parameters}

The sources of hospital exposure to ionizing radiation in our series were largely dominated by conventional radiography and CT scanning. Maintenance and quality control of the equipment is necessary as these defects accentuate the production of scattered radiation which results in unnecessary irradiation of patients and the production of poor resolution images. In our developing countries, the maintenance of radiology equipment is precarious and a certain number of machines are obsolete with an operating life of more than 10 years. This was confirmed by Kouassi et al. in a study carried out in Ivory Cost in 2005 where they found that $61.5 \%$ of the equipment had been in use for more than ten years [7].

In this study, the average duration of exposure varied according to the facilities. Indeed, the daily exposure mode is about eight hours. This poses a real problem, as we know that the longer the exposure time, the more likely it is that stochastic effects will lead to genetic effects and cancer.

Other medical imaging modalities that do not use ionizing radiation, such as ultrasound and magnetic resonance imaging, provide an alternative way of managing the duration of exposure to radiogenic sources.

\subsection{Medical and Dosimetric Monitoring}

The absence of a health structure for monitoring workers who were not able to benefit from a single chest X-ray examination during their recruitment and were not monitored periodically. This follow-up should allow early detection of pre-cancerous lesions and the organization of therapeutic and medico-legal management of radiation-induced pathologies. Mbo Amvene et al. made the same observation in the imaging departments of hospitals in the far north of Cameroon in 2017. The same is true for Houndétoungan in hospitals in south-eastern Benin in 2015 [10] [11].

As for dosimetric monitoring, only $11.47 \%$ of workers had benefited from it. And yet, all workers exposed to ionizing radiation must have medical and dosimetric monitoring. Depending on their activity and level of exposure, this may be a passive or active dosimeter. The accumulation of the doses received helps the occupational physician to anticipate the occurrence of radiation-induced pathologies. To avoid this situation, biological examinations such as blood counts should be carried out on these workers, as it has been clearly established by authors 
such as Jimonet et al. in 2007 that even low-dose exposures are likely to have harmful effects on workers [12].

\subsection{Compliance with Radiation Protection Measures}

The practical implementation of radiation protection measures is mainly based on the interposition of protective shields, the distance from the source and the reduction of the exposure time.

Interposition of protective screens

The plumber's apron is the most commonly used personal protective equipment. Fifty-seven workers under ionizing radiation, i.e. 93.44\%, often wear personal protective equipment if the situation requires it. Studies on compliance with radiation protection measures in other African countries with national regulations have also shown an acceptable level of compliance with regard to the wearing of aprons. Indeed, Kouassi et al. in Abidjan in 2005 [7] and Tapsoba et al. in Ouagadougou [8] had reported that more than $90 \%$ of workers protected themselves with a lead apron. Jaouad noted this in $80 \%$ of his respondents in 2013 in Marrakech [6]. In contrast, Khaled found a proportion of 50\% use of plumber's aprons by workers in his 2010 study in the health care facilities of the city of Sidi Bel-Abbés [9]. The lack of regular wearing of lead aprons is indicative of the lack of rigor of the staff with regard to their own protection. It was considered as "a waste of time" for the performance of an examination or simply "useless because the screen protects enough" according to some workers. The other reason most mentioned was its heaviness. However, according to Menechal et al. certain types of apron are more easily used and well tolerated because they are more adapted to the worker's morphology and lighter [13].

As for the other protective equipment (thyroid protectors, goggles, leaded gloves), they were almost never used in the departments that had them. Kouassi et al. [7] in Abidjan made the same observation, while in Marrakech, Jaouad found that only $17.9 \%$ of workers used them [6].

\section{Reduction of exposure time}

The daily time spent in the medical imaging room ranged from 2 hours to more than 8 hours. For work-related constraints, thirty workers (49.18\%) remained in the room while the X-ray tube was active.

Eight workers (13.11\%) were in the room outside of work constraints while the X-ray tube was inadvertently activated due to the absence of light signals. This malfunction increases the exposure time of the workers with an additional accumulation of absorbed dose.

Administrative measures such as technical leave, alternating shifts are not applied for all categories of workers. Forty-five workers interviewed had never benefited from radiation leave (73.77\%). Assistant technicians and doctors in training, who do not have administrative status, constitute the largest number of workers and do not have radius leave. Khaled et al. found in their study in Algeria in 2010 that only $20 \%$ of workers benefited from it [9]. 
The involvement of the administrative authorities of the hospital structures, the Ministry of Health, the Ministry of Employment and Labour and the authorities of the medical imaging department is necessary for the proper harmonization of these leaves, which will substantially promote the reduction of workers' exposure time to ionizing radiation.

Distance from the Source

Fifteen workers, or $24.60 \%$ of the imaging staff, were not concerned about the regulatory distance from the ionizing radiation source. Staff should, at all times, keep as far away as possible from the source of ionizing radiation. Personnel should never be allowed direct exposure to the primary radiation beam [14].

It is therefore important to comply with building standards, to carry out a good zoning of the premises and to regularly carry out a good study of the workstation to ensure optimal protection of the worker [15]. This is difficult to achieve in the absence of a PCR.

\section{Conclusion}

In Senegal, level III health structure has the most qualified medical staff and despite everything, this study still shows an embryonic state of radiation protection for workers, even fewer patients subjected to ionizing radiation for diagnostic and therapeutic purposes. This is clearly explained by the absence of Qualified Expert in Radioprotection (QER) in most of our departments. The QEC plays a key role. Indeed, it carries out the technical expertise (job study) allowing the classification of radiology rooms by the employer ("zoning"). It ensures that these areas are properly marked and sets up ambient dosimetry. She takes care of dosimetric monitoring requests. It also allows the collection and dispatch of passive dosimeters and at the same time intervenes in the management, prevention and training of newly assigned personnel on the specifics of the service. To give an important place to radiation protection, quality control of radiology equipments is needed to optimize the doses delivered to patients. That will instill in workers a real "radiation protection culture".

\section{Conflicts of Interest}

The authors declare that they have no conflicts of interest.

\section{References}

[1] Arrivé, L. (2012) Modalités Radiologiques. In: Miquel, A. and Monnier-Cholley, L., Eds., Imagerie Médicale Pour le Clinicien, Elsevier Masson, Paris, 1-38. https://doi.org/10.1016/B978-2-294-71238-8.00001-1

[2] Gervaise, A., Esperabe-Vignau, F., Pernin, M., Naulet, P., Portron, Y. and LapierreCombes, M. (2011) Évaluation des connaissances des prescripteurs de scanners en matière de radioprotection des patients. Journal de Radiologie, 92, 681-687.

[3] Nénot, J.C., Brenot, J., Laurier, D., Rannou, A. and Thierry, D. (2007) Recommandations 2007 de la Commission internationale de protection radiologique. ICRP Publication, New Delhi. 
[4] Aurengo, A., Petitclerc, T. and Kas, A. (2013) Biophysique. 4th Edition, Lavoisier SAS, Paris.

[5] Gouvernement du Sénégal (2004) LOI n² 2004-17 du 15 juin 2004abrogeant les dispositions de la loi $\mathrm{n}^{\circ}$ 2001-01 du 3 janvier 2001 relative à la protection contre les rayonnements ionisants. Journal Officiel du Sénégal, nº 6177.

[6] Jaouad, S. (2013) Étude de l'observance des règles de la radioprotection en radiologie conventionnelle dans les hôpitaux SEGMA de la Région Marrakech Tensift al Haouz.

[7] Kouassi, Y.M., Wognin, S.B., Tchicaya, A.F., Alla, D. and Bonny, J.S. (2005) Étude de l'observance des règles de radioprotection en milieu hospitalier à Abidjan. Archives des Maladies Professionnelles et de P Environnement, 66, 369-374. https://doi.org/10.1016/S1775-8785(05)79108-6

[8] Tapsoba, T., Ouattara, T., Belemlilga, H.G.L., Sanon, H., Bamouni, Y.A., Ouédraogo, V., et al. (2010) Application des règles de protection contre les rayons $\mathrm{X}$ dans les services de radiologie de Ouagadougou. Médecine Nucléaire, 34, e9-e12. https://doi.org/10.1016/j.mednuc.2010.07.011

[9] Khaled, A., Ghomari, O. and Kandouci, A.B. (2010) La radioprotection dans les établissements de soins utilisant les rayons X: évaluation et constats dans la ville de Sidi Bel-Abbès. Sidi Bel-Abbès, Algérie.

[10] Amvene, J.M., Djonyang, B., Amougou, J.M., Ngaroua, D. and Amvene, S.N. (2017) Observance des Règles de Radioprotection dans les Services d'Imagerie des Hôpitaux de l'Extrême-Nord du Cameroun. Health Sciences and Disease, 18, 83-87.

[11] Houndetoungan, G.D. (2015) Evaluation de l'observance des mesures de radioprotection des travailleurs dans les services de radiologie de l'ouémé et du plateau au Bénin en 2015 [Mémoire de DES, Biologie médicale et sciences fondamentales, Biophysique]. Faculté des Sciences de la Santé de Cotonou.

[12] Vaillant, L. and Schneider, T. (2012) Evaluation du détriment associé à l'exposition aux faibles doses et faibles débits de dose dans le système de radioprotection. Environnement, Risques \& Santé, 11, 149-159.

[13] Menechal, P., Valero, M., Megnigbeto, C., Marchal, C. and Godet, J.L. (2011) La radioprotection des patients et des travailleurs en radiologie interventionnelle et au bloc opératoire. INRS (Institut National de Recherche et de Sécurité), 222, 27-33.

[14] Association Française de Normalisation (2011) Normes Française de Construction (NFC). 15-160.

[15] Cordoliani, Y.S. and Foehrenbach, H. (2014) Radioprotection en milieu médical: principes et mise en pratique. 3rd Edition, Elsevier Masson, Paris, 230. 